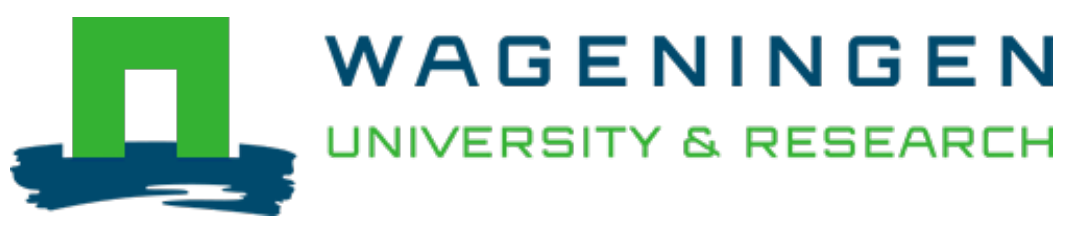

\title{
Role of fungi in cyanogens removal during solid substrate fermentation of cassava
}

Biotechnology Letters

Essers, A.J.A.; Witjes, C.M.J.W.; Schurink, E.W.; Nout, M.J.R.

https://doi.org/10.1007/bf00136486

This publication is made publicly available in the institutional repository of Wageningen University and Research, under the terms of article $25 \mathrm{fa}$ of the Dutch Copyright Act, also known as the Amendment Taverne. This has been done with explicit consent by the author.

Article $25 \mathrm{fa}$ states that the author of a short scientific work funded either wholly or partially by Dutch public funds is entitled to make that work publicly available for no consideration following a reasonable period of time after the work was first published, provided that clear reference is made to the source of the first publication of the work.

This publication is distributed under The Association of Universities in the Netherlands (VSNU) 'Article $25 \mathrm{fa}$ implementation' project. In this project research outputs of researchers employed by Dutch Universities that comply with the legal requirements of Article $25 \mathrm{fa}$ of the Dutch Copyright Act are distributed online and free of cost or other barriers in institutional repositories. Research outputs are distributed six months after their first online publication in the original published version and with proper attribution to the source of the original publication.

You are permitted to download and use the publication for personal purposes. All rights remain with the author(s) and / or copyright owner(s) of this work. Any use of the publication or parts of it other than authorised under article $25 \mathrm{fa}$ of the Dutch Copyright act is prohibited. Wageningen University \& Research and the author(s) of this publication shall not be held responsible or liable for any damages resulting from your (re)use of this publication.

For questions regarding the public availability of this publication please contact openscience.library@wur.nl 


\title{
ROLE OF FUNGI IN CYANOGENS REMOVAL DURING SOLID SUBSTRATE FERMENTATION OF CASSAVA
}

\author{
A.J. Alexander Essers', Claudia M.J.W. Witjes, Erna W. Schurink and M.J. Robert Nout \\ Department of Food Science, Wageningen Agricultural University, \\ Bomenweg 2, 6703HD Wageningen, The Netherlands
}

\begin{abstract}
SUMMARY
Disinfected cassava root pieces were incubated with and without fungal inoculation. The resulting flours from non-inoculated incubated cassava showed significantly lower $(P=0.004)$ cyanogenic glucoside levels than those from non-incubated cassava, and significantly higher $(\mathrm{P}<0.0001)$ levels than those from the fermented pieces. The fungi played a role in the reduction of the cyanogenic glucoside levels.
\end{abstract}

\section{INTRODUCTION}

Cassava, a high yielding starchy root crop from the tropics, contains cyanogenic glucosides, nearly all in the form of linamarin. These glucosides may be degraded to the toxin hydrogen cyanide by endogenous linamarase activity through the intermediary of cyanohydrins. Consequently, they must be removed before consumption (Cock, 1982). Cyanogen reduction is an important criterion in the great variety of processing methods that have been developed over time in cassava growing areas (Lancaster et al., 1982). One of these methods, practised in Uganda, involves fungal solid substrate fermentation. After this fermentation, the roots are sun-dried and further processed into flour. It was found that the fermentation stage contributed significantly to the reduction of cyanogen levels (Essers et al., 1994). It was not known, though, whether the incubation itself was responsible for this reduction by endogenous activity, or if the microflora contributed to this effect. In the predominantly lactic acid bacterial fermentation during processing of gari, a West African cassava product, the microflora played no positive role in the cyanogen removal (Vasconselos et al., 1990), while during the process of soaking in water for fufu manufacture, the microflora contributed to cyanogen removal only by softening the cassava tissue (Westby and Twiddy, 1992).

This article reports on the linamarin diminishing effect from fungal pure cultures, additional to that from endogenous enzymes, during solid substrate fermentation of cassava.

\section{MATERIALS AND METHODS}

\section{Experimental}

Fresh cassava roots from Costa Rica were peeled and split lengthwise into 4 segments. Each segment was cut transversally into pieces of approx. $50 \mathrm{~g}$ which were matched to obtain 7 batches with comparable cyanogen levels. The pieces of 6 batches were submerged for 30 $\mathrm{sec}$ in, successively, ethanol $(70 \% \mathrm{v} / \mathrm{v})$ and oxytetracycline $(0.5 \mathrm{~g} / \mathrm{l}$ distilled water $)$, after 
which they were forced-air dried for $1 \frac{1}{2} \mathrm{~h}$ at $50^{\circ} \mathrm{C}$, reducing the moisture content to approx. $50 \%$ of total weight basis. (In experiment 3 submersion in ethanol was omitted.) After the pre-treatment, 5 batches were incubated during 96 hours at $30^{\circ} \mathrm{C}$; three of them after inoculation with respectively Rhizopus oryzae, Neurospora sitophila and Geotrichum candidum, and two batches served as non-inoculated incubated controls.

After incubation, the pieces were washed with distilled water to remove the mycelia, diced to facilitate drying and forced-air dried at $50^{\circ} \mathrm{C}$ for 2 days. One batch of fresh and one of pre-treated cassava were also dried without incubation. All dried samples were pulverized in a mortar and ground into flour in a mill (Fritsch Pulverisette type 14.702, Idar-Oberstein, Germany) in two further steps through a 4 and $1 \mathrm{~mm}$ sieve, and subsequently extracted and analysed for cyanogens according to Essers et al. (1993). The experiment was repeated with fresh roots from Ghana (experiment 2). For confirmation of the results from these two experiments, a similar third experiment was carried out with cassava roots from Costa Rica, using inocula of Rhizopus oryzae, Rhizopus stolonifer and Neurospora sitophila and an incubation time of 72 hours at $26^{\circ} \mathrm{C}$. In the latter experiment, cyanogens were also assayed in moist incubated pieces prior to removing mycelia and drying.

\section{Preparation of inoculum}

The fungi Rhizopus oryzae, Rhizopus stolonifer, Neurospora sitophila and Geotrichum candidum had been isolated earlier from traditionally heap-fermented cassava flour from Uganda (Essers et al., 1994). In the first two experiments, sterilized water was added to a petri dish with sporulated pure culture and a spore suspension was collected in a sterile test tube after mildly shaking. The number of spores per $\mathrm{ml}$ suspension was assayed by plate count in malt extract agar (Oxoid CM 59). Inoculation level was $10^{4} \mathrm{cfu} / \mathrm{g}$ cassava, corresponding to $1-2 \mathrm{ml}$ of spore suspension. In the third experiment the cassava pieces were inoculated directly by pressing them on sporulated pure cultures in petri dishes.

\section{Statistical analysis}

The treatment effects were evaluated for statistical significance by two way analysis of variance with factors replicates and treatments (Snedecor and Cochran, 1980, p 255).

\section{RESULTS}

The disinfection pre-treatments proved reasonably successful. In all three experiments the inoculated fungi grew well, whilst none of the incubated control batches were visibly overgrown by fungi. On some of the incubated cassava pieces slime had developed, indicating bacterial growth. In experiments 1 and 2, mycelial growth was satisfactory on the $G$. candidum and good on the $R$. oryzae and $N$. sitophila inoculated batches. In experiment 3 , mycelial growth was satisfactory on the $R$. stolonifer, good on the $N$. sitophila and very good on the $R$. oryzae inoculated batch.

Table 1 shows the residual cyanogen levels in cassava flours from experiments 1 and 2 . Figure 1 illustrates the residual cyanogen levels in moist products and their flours of incubated control and fungal inoculated cassava of experiment 3.

The pre-treatment did not significantly influence cyanogen levels in the cassava pieces.

In experiments 1 and 2 , the mean difference in cyanogenic glucoside levels between flours from non-inoculated and incubated, versus non-incubated root pieces was $8.9 \mathrm{mg} \mathrm{CN}$ equivalents $/ \mathrm{kg}$ dry weight (SD 4.8). This difference was significant at $P=0.004$, one-sided. 
Equally, the difference in cyanogenic glucoside levels between flours from inoculated and incubated, versus only incubated control root pieces was $5.1 \mathrm{mg} \mathrm{CN}$ equivalents $/ \mathrm{kg}$ dry weight. (SD 1.6). This was also highly significant ( $\mathrm{P}<0.0001$, two-sided).

Table 1: Residual moisture and cyanogen levels in cassava flour after different treatments (experiments 1 and 2)

\begin{tabular}{ccc}
\hline treatment & moisture & cyanogens (mg CN equiv./kg dry wt) \\
& $(\%)$ & $\left.\left.\mathrm{CNp}^{1}\right) \mathrm{CN}_{\text {-glucosides }} \mathrm{nCN}^{2}\right)$ \\
\hline
\end{tabular}

(Experiment 1) - - roots from Costa Rica - -

$\begin{array}{lrrrr}\text { none } & 8.6 & 15.1 & 12.5 & 2.6 \\ \text { only disinfected } & 11.0 & 13.6 & 10.7 & 2.9 \\ \text { incubated control } & 5.8 & 7.3 & 5.9 & 1.4 \\ \text { incubated control } & 9.3 & 8.2 & 7.6 & 0.5 \\ \text { incub./ } R \text {. oryzae } & 5.5 & 0.9 & 0.2 & 0.7 \\ \text { incub./ } N \text {. sitophila } & 12.5 & 0.6 & 0.0 & 0.6 \\ \text { incub./ G. candidum } & 10.3 & 2.5 & 0.8 & 1.8\end{array}$

(Experiment 2) - roots from Ghana-.

$\begin{array}{lrrrr}\text { none } & 14.0 & 22.7 & 17.9 & 4.8 \\ \text { only disinfected } & 13.0 & 26.5 & 20.9 & 5.6 \\ \text { incubated control } & 5.6 & 8.8 & 6.0 & 2.9 \\ \text { incubated control } & 5.5 & 9.1 & 6.8 & 2.3 \\ \text { incub./ } R \text {. oryzae } & 4.8 & 3.1 & 2.2 & 0.9 \\ \text { incub./ N. sitophila } & 5.3 & 2.7 & 2.1 & 0.5 \\ \text { incub./ G. candidum } & 6.3 & 4.0 & 3.5 & 0.5\end{array}$

1) $\mathrm{CNp}=$ cyanogenic potential: cyanogenic glucosides plus ngCN

$\left.{ }^{2}\right) \mathrm{ngCN}=$ non-glucosidic cyanogens: cyanohydrins plus $\mathrm{HCN}$

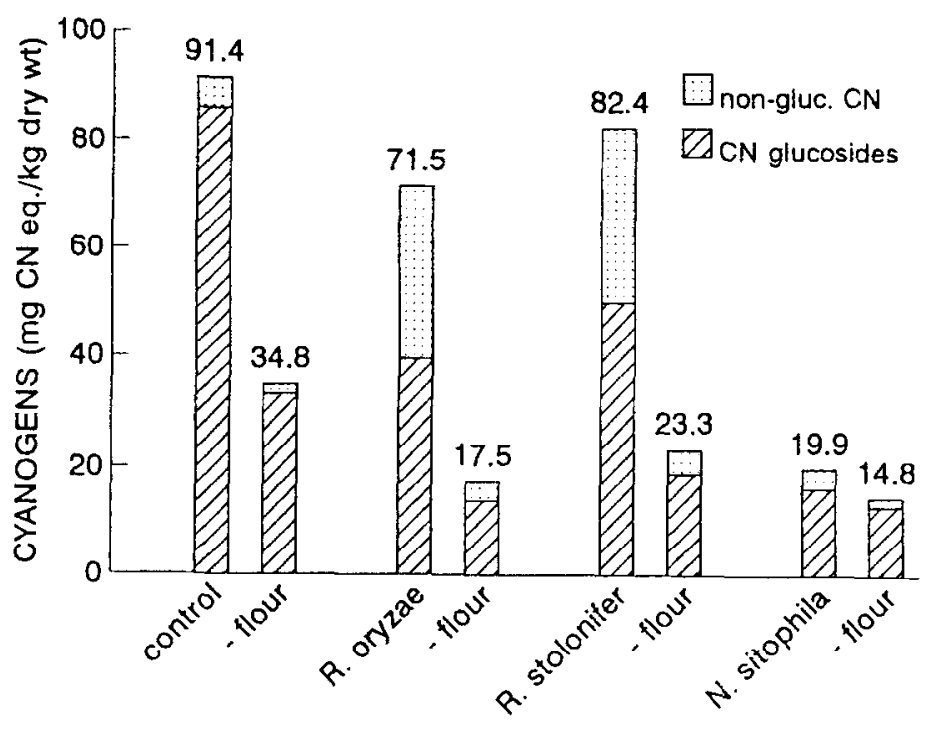

Fig. 1. Residual cyanogen levels in 4 moist batches of incubated (Costa Rican) cassava pieces, of which 3 inoculated with fungi, and their respective flours (experiment 3 )

TREATMENT 


\section{DISCUSSION}

Incubation of disinfected cassava pieces already effectuated significantly reduced cyanogenic glucoside levels in the resulting flours. A minor influence of contaminating microbial activity during this test can not be excluded. Other trials indicated that absolute sterility could only be achieved with gamma-irradiation or thorough heat treatment. Since both strongly affect the texture, starch accessibility, enzyme activity and cyanogen levels in cassava, these options were not suitable alternatives.

The treatment effect in experiment 3 was less pronounced than in the other two, due to the shorter incubation and lower temperature, but basically the same. It also showed the cyanogen lowering effect of the final drying step. Although batches inoculated with Neurospora sitophila showed lowest cyanogen levels, these levels in the fermented cassava in experiment 1 were below the assay's accuracy limit, implying that statistical testing would not be meaningful. This trend should be tested in further experiments.

The only difference between the fermented batches and their controls was the inoculation with fungi and their subsequent growth. Inoculation in the first two experiments involved some slight additional moisture during incubation, which was avoided in the third experiment, still yielding the same cyanogen lowering effect.

The consistently and significantly lower levels of cyanogenic glucosides in all fermented cassava samples compared to their unfermented controls in 3 independent experiments, indicate that the fungi enhanced in some way the breakdown of cyanogenic glucosides in cassava.

These findings imply that induced fungal activity, in addition to the endogenous activity during the incubation itself as well as the drying step, contributes to the cyanogen level reduction in the process of solid substrate fermentation of cassava as practised in Uganda.

\section{REFERENCES}

Cock, J.H. (1982). Cassava: A basic energy source in the tropics. Science, 218, 755-762.

Essers, A.J.A., Bosveld, M., Van der Grift, R.M. and Voragen, A.G.J. (1993). Studies on the quantification of specific cyanogens in cassava products and introduction of a new chromogen. J. Sci. Food Agric. 63 (3), 287-296.

Essers, A.J.A., Ebong, C., Van der Grift, R.M., Otim-Nape, W. and Nout, M.J.R. (1994). Detoxification of cassava by heap-fermentation in Uganda. In: Proceedings of the fifth seminar of the ISTRC-AB, Kampala 26 - 29 December 1992. (in print)

Lancaster, P.A., Ingram, J.S., Lim, M.Y., \& Coursey, D.G. (1982). Traditional cassava based foods: Survey of processing techniques. Economic Botany 36 (1), 12-45.

Snedecor, G.W. and Cochran, W.G. (1980). Statistical Methods. $7^{\text {th }}$ ed. Iowa State Univ. $507 \mathrm{pp}$.

Vasconcelos, A.T., Twiddy, D.R., Westby, A. and Reilly, P.J.A. (1990). Detoxification of cassava during gari preparation Int. J. Food Sci. Techn. 25, 198-203.

Westby, A. and Twiddy, D.R. (1992). Role of micro-organisms in the reduction of cyanide during traditional processing of African cassava products. In: Westby, A. and Reilly, P.J.A. (Eds.) Proceedings of a regional workshop on traditional African foods - Quality and Nutrition. 25-29 Nov. 1991. International Foundation for Science, Stockholm, Sweden. Pp 127-131. 